Article

\title{
Analysis Of Russia's Approach To Kyoto Protocol: Russia's Withdrawal From Second Commitment Period (2013-2020)
}

Nur Yasmin Ghafiel ${ }^{1}$, Paramitaningrum ${ }^{2}$

${ }^{1}$ Ilmu Hubungan Internasional,Bina Nusantara University, Indonesia

\section{SUBMISSION TRACK}

$\begin{array}{ll}\text { Recieved } & : 06 \text { March } 2020 \\ \text { Final Revision } & : \text { 05 October 2020 } \\ \text { Available Online } & : \text { 30 November 2020 }\end{array}$

KEYWORD

Kyoto Protocol, Russia, Offensive Realism

KATA KUNCI

Protokol Kyoto, Rusia, Realisme ofensif

CORRESSPONDENCE

E-mail : : paramitaningrum@binus.edu

\section{A B S T R A C T}

In 2004 Russia ratified the Kyoto Protocol, one of the international agreements which focus on climate change mitigation. Russia officially participated in the Kyoto Protocol's first commitment period in 2005 after ensuring the benefits by doing so. Entering the second commitment period, in 2011, Russia decided to withdraw. In consideration of Russia's position as the most abundant fossil fuel energy exporter and as a country whose economy is in restoration. This paper analyzes Russia's withdrawal from the second commitment period of the Kyoto Protocol through the perspective of offensive realism with a qualitative methodology. This paper finds that foreign policy and, in a more modern sense, a need to take "good Samaritan," a politically correct role for the global community, was the main reason of Russia's' withdrawal from the Protocol.

\section{A B S T R A K}

Pada tahun 2004 Rusia meratifikasi Protokol Kyoto, salah satu perjanjian internasional yang berfokus pada mitigasi perubahan iklim. Rusia secara resmi berpartisipasi dalam periode komitmen pertama Protokol Kyoto pada 2005 setelah memastikan keuntungan yang akan didapat setelahnya. Memasuki periode komitmen kedua, pada 2011 Rusia memutuskan untuk mundur. Mempertimbangkan posisi Rusia sebagai pengekspor energi bahan bakar fosil terbesar dan sebagai negara yang ekonominya dalam pemulihan. Makalah ini menganalisis faktor-faktor di balik penarikan Rusia dari periode komitmen kedua Protokol Kyoto melalui perspektif realisme ofensif dengan metodologi kualitatif. Penelitian ini menemukan bahwa di balik alasan penarikan Rusia, langkah negara itu sangat dipengaruhi oleh kebijakan luar negeri dan, dalam pengertian yang lebih modern, kebutuhan untuk mengambil peran "orang Samaria yang baik hati" dan yang benar secara politis bagi komunitas global 


\section{Introduction}

Russia had a crucial role in the ratification of Kyoto Protocol, especially since this country is one of the most significant carbon emission contributors. At the same time, other countries that also falls in the same category (the United States and China) refused to ratify. Thus, Russia has a bargaining position ${ }^{1}$ Due to that, the Protocol needs at least 55 ratifying countries or $55 \%$ of 1990 emission contributors to be enforced, and Russia represents $17,4 \%$ of total carbon emissions in said year. Such a position creates a mixed impact for Russia. The government was split into two sides on Kyoto Protocol ratification, noting that Russia's growing economy could strongly be affected. Although it is internally opposed, Russia gained support from the European Union (EU) to become a member of the World Trade Organization (WTO) in return for Russia's ratification to the Kyoto Protocol.

Aside of that tempting promise, by ratifying the Kyoto Protocol and noting that it is a binding agreement, Russia then commits to abide by the terms. Consequently, Russia must fulfill the given targets and requirements. In addition to that, Russia must have a specific policy which specifically made to internalize the Protocol domestically. Efforts done by Russia included but were not limited to participation in the Joint Implementation (JI) mechanism, the formation of the legislative framework and The Action Plan on the Kyoto Protocol, and national climate policy, Climate Doctrine. ${ }^{2}$ However, while being implemented, those efforts did not work as expected.

Entering the Kyoto Protocol's second commitment period in 2013-2020, Russia

\footnotetext{
${ }^{1}$ in negotiations, according to his ability to achieve a goal or agreement under their wishes.

2 Anna Firsova, Taplin, R., "A Review of Kyoto Protocol Adoption in Russia: Joint Implementation in Focus", Transition Studies Review 15 (Germany: Springer-Verlag, 2008), 480-498.
}

announced their withdrawal from the Protocol at COP 17 in Durban, South Africa, in 2011. As said by Russian Climate Change Envoy, Alexander Berditsky, "Russia will not participate in the Kyoto Protocol's second commitment period." ${ }^{3}$ This announcement indicated a change in Russia's stance to the Protocol from active participation to the opposite.

It is interesting to discuss the causative factors that made Russia withdraw from the global climate change agreement, which is very crucial for global security to which Russia acknowledged. While other research circulate Russia's first period in the Protocol, there is a limited analysis of Russia's withdrawal from the second period. Considering Russia's national interest and position as both the most significant world's fossil fuel exporter and the world's biggest carbon emitter, surely the energy sector is very keenly observed. Therefore, it is also necessary to see the factors of why Russia withdrew from the second commitment period of the Protocol.

\section{Research Method}

This issue is discussed through the theory of offensive realism by John J. Mearsheimer from his book, "The Tragedy of Great Power Politics" 4. Mearsheimer argued that: first, the international system is anarchy; second, the great powers have offensive military power; third, states will never be certain of other states' intentions; fourth, survival is the main purpose of great power states; and fifth, the great powers are rational actors.

Furthermore, Mearsheimer argued that states would depend on themselves to

\footnotetext{
3 Suzanne Goldenberg, "Cancun Climate Change Conference: Russia Will Not Renew Kyoto Protocol", The Guardian, December 102010 , www.theguardian.com/environment/2010/dec/10/ca ncun-climate-change-conference-kyoto.

${ }^{4}$ John J. Mearsheimer, The Tragedy of Great Power Politics, (New York: Norton, 2001)
} 
ensure the safety of their country, hence the best strategy for states to achieve that is by power maximization ${ }^{5}$. Also emphasizing on Russia's national interest conception, which according to the National Security Concept of the Russian Federation, is "a totality of balanced interests of the individual, society and the state in economic; domestic political, social, international, informational, military, border, environmental and other fields." It is stated that in "Ensuring national security, the Russian Federation involves the following main tasks:

- Developing the country's economy and pursuing independent and socially oriented economic policies;

- Radically improve the ecological situation in the country;

- Ensuring national security and protecting Russian interests in the economic sphere are the priority thrusts of state policy." 6

Regarding this case, Russia's national interest, especially in the economic and environmental fields, will be touched. In the economic field, it was said that Russia's national interest was "sustainable economic development." The threats to this interests are, among other things: "a substantial contraction in the gross domestic product (GDP); a drop in investment and innovation activities; the dwindled scientific and technological potential ... the tendency for the prevalence in exports supplies of fuels, raw materials, and energy components, and

\footnotetext{
${ }^{5}$ Colin Elman, "Realism”, International Relations Theory for the Twenty-First Century, Oxon: Routledge, 2007) p. 18; John J. Mearsheimer, "Structural Realism", in T. Dunne, M. Kurki, S. Smith, International Relations Theory: Discipline and Diversity Ed.3, pp. 77-93, (Oxford: Oxford University Press, 2012)

${ }^{6}$ Russian Federation, National Security Concept of the Russian Federation (Moscow: Russian Federation, 2000) http://www.mid.ru/en/foreign_policy/official_docu ments/-

/asset_publisher/CptICkB6BZ29/content/id/589768
}

in imports supplies - food and consumer items, including articles of prime necessities.". 7 Then, it is reasonable why the economy is the top priority of Russian policy. The economic sector will support other sectors such as security and the military, politics, society, and others. Thus, Russia needs a strong and stable economy. In the field of environment, it was stated that "The threat of a deteriorating environmental situation in this country and the depletion of its natural resources depend directly on the state of the economy and the society's willingness to grasp the globality and importance of these issues. For Russia, this threat is enormous because of the preferential development of fuel and energy industries, the lack of development in the legislative framework for environmental activities, the absence or limitations of resource conservation technologies, and low environmental awareness. There is a tendency for Russia to be used as a place to reprocess and bury materials and substances that are harmful to the environment.". 8 From the abovementioned paragraph, it was concluded that Russia recognized the existence of flaws in the legislative framework for environmental activities. From this point of view, it appears that Russia handled environmental threats in its country into the hands of its people. It also appears that there is no specific vision to deal with this problem. Such a condition shows Russia's position on climate change and has consequences for its position on the regime of this issue.

Hence, this research would discuss the reason behind Russia's withdrawal by identifying the threats and interests or benefits to Russia by being in Kyoto Protocol through the offensive realism perspective variables: power maximization and cost and benefit calculation. The first section explains the Kyoto Protocol and the

\footnotetext{
${ }^{7}$ Russian Federation, 2000

${ }^{8}$ Russian Federation, 2000
} 
dynamics in Russia's ratification process. The second section discusses the efforts done by Russia in internalizing the Protocol and the outcomes. The third section analyzes Russia's withdrawal through the provided perspective. The final section provides a concluding statement on this issue.

\section{Result and Discussion}

\section{Protocol Kyoto and Russia's Ratification}

The Kyoto Protocol is one of the mechanisms under the United Nations Framework Convention on Climate Change (UNFCCC) created in 1997 in Kyoto, Japan. This Protocol contains an outline of the necessary actions needed to deal with climate change and strengthen the UNFCCC to achieve its objectives. This Protocol is legally binding. It sets targets for each Annex I member country, consisting of 41 industrialized countries, to reduce greenhouse gas emissions by at least $5 \%$ of the emission level in 1990 and to help developing countries overcome climate change. Such an arrangement is because of the shared understanding that industrialized countries are important actors responsible for climate change through industrial emissions. The Countries which fail in meeting their emission targets are required to cover the difference between the emission targets and their actual emissions, plus a $30 \%$ penalty for the following period. The country cannot participate in the emissions trade until considered to comply with this Protocol.

Russia signed the Kyoto Protocol in 1999 and ratified it in 2004. This ratification also complemented the requirement that the Protocol came into force in 2005. There was a long process to ratify the Kyoto Protocol, due to several problems and circumstances. Under the Kyoto regulation, Russia needs to reduce its emissions by a target of $0 \%$, which means it should not exceed its emission level in 1990 or around 3000 million tons of $\mathrm{CO} 2$. By ratifying this Protocol, Russia has also committed to formulate and implement national actions and policies to reduce greenhouse gas emissions. In this effort, the Kyoto Protocol has provided three mechanisms, namely: (1) emissions trading; (2) joint implementation (JI), and (3) the Clean Development Mechanism (CDM). Russia itself hoped to play a significant role in these mechanisms, especially emissions trading and JI.

\section{Pre-ratification Debate}

Domestically, there was a debate on the issue of the Kyoto Protocol's ratification. Legislation of the State Duma generally supports, except Andrei Illarionov, the President's economic adviser, who rejects Russia to ratify it. Illarionov rejected the idea added that Russia would experience an economic recovery and would exceed its emissions quota. Russia also must comply with the commitment to reduce emissions, which would cause the country to limit industrial activity and energy use, which will have an impact on economic growth. He had a negative view of the Kyoto Protocol's ratification, mainly because it would hamper Russia's economic growth. Illarionov himself was a member of the Advisory Board of the Russian Academy of Sciences. The agency examined the Kyoto Protocol and revealed that it would have several negative impacts on Russia, such as the main points of his arguments:

a. The Kyoto Protocol does not have a scientific or scientific basis;

b. The Kyoto Protocol will not be effective in achieving the objectives of the UNFCCC;

c. The warmth of the climate for cold Russia can have positive effects such as reduced energy uses for heating and increased food production; 
d. Due to the rapid growth of GDP in Russia, the Kyoto Protocol can provide serious economic risks and eventually limit GDP growth.

The industrial sector in Russia also believes in this. They see the excellent prospect of the JI project, namely technology the modernization, and project financing related to energy efficiency. The industrial sector had a significant contribution to the Russian economy, especially the energy industry sector, such as the Gazprom company and OAO RAO UES (OAO Unified Energy System of Russia). This is because Russia has $58 \%$ of the total JI market with potential emissions reductions of more than $150 \mathrm{Mt} \mathrm{CO} 2 \mathrm{e}$.

On the other hand, the main argument of the supporters is that Russia has an opportunity to increase its economy with its emission surplus quota and joint implementation. By regulating emission reduction, Russia could reduce the intensity of energy use and save state revenues and double its GDP. For example, environmental NGOs see that by ratifying the Kyoto Protocol, Russia will have a mechanism that regulates greenhouse gas emissions produced by its domestic activities, extraordinarily inefficient industries. WWF Russia is one of the international NGOs that supports the ratification of the Kyoto Protocol. However, NGOs in Russia have a limited role in influencing the Russian government due to the country's political atmosphere, in which the non-state actors are not one of the main actors. Therefore, the negative opinion about the Kyoto Protocol is still more reliable.

Despite all the debate, Russia saw that the Kyoto Protocol's ratification is strategic for its international exposure. Russia was offered to be a member of WTO and was given strong support from the EU if this country is willing to ratify the Kyoto Protocol. Russia has been aspiring to join WTO since $1992 .{ }^{9}$ The initial negotiation process has been postponed for a while because of the Russian Ruble crisis in $1998 .^{10}$ When Vladimir Putin came to power in 2000 as a president, the prospect of Russian membership in the WTO became crucial.

For Putin, the consideration of facilitating Russia becoming a member of the WTO is an excellent opportunity to be gained from ratifying it, and that Putin takes this into account as a political advantage for Russia and an achievement for him as President. WTO's membership will affect the growth of the Russian economy. According to World Bank, WTO membership in Russia will provide $3 \%$ GDP growth in the medium term and $11 \%$ in a long time, especially with improved service quality and reduced prices in the domestic market.

Furthermore, Russia has a decisive role in this Protocol that gives Russia image elevation in the international community. As the European Union strongly supports and seeks to implement the Kyoto Protocol, Russia's refusal to ratify would strongly affect its relationship with Europe. Russia will also be deemed not to support a shared agenda aimed at the safety of the world. Conversely, if Russia ratifies, Russia will be considered a 'savior' which helps the environmental plan. It will also show that Russia is cooperative with the European Union, one of the distinguished global environmental actors. Putin himself would be seen a good person.

Thus, on October 22 2004, the State of Duma voted 334-73 and approved the treaty. It can be argued that Russia's

\footnotetext{
${ }^{9}$ Yasin, Yevgeny (2002), Russia and the WTO, in Barysch, Katinka, Cottrell, Robert, Frattini, Franco, Hare, Paul Lamy Pascal, Medvedkov, Maxim, and Yasin, Yevgeny, "Russia and the WTO" Centre for European Reform 2012, https://www.cer.eu/sites/default/files/publications/at tachments/pdf/2011/p394_russia_wto-1663.pdf: page 5

${ }^{10}$ Ibid
} 
participation in the Kyoto Protocol's first commitment period was then due to opportunities that would benefit Russia, which later became an interest in making such decisions, including:

- Economic benefits: Russia's potential to sell its 'hot air' will contribute significantly to the Russian economy. The potential for carrying out joint implementation (JI) projects is also significant so that participating in Russia can attract investors for the JI project.

- Political advantage: The European Union's support for Russia's membership in the WTO will be a good step for the Russian economy. Russia will have a say in international trade negotiations. WTO membership will also help Russia to conduct its economic reform. $^{11}$ It also shows that Russia - EU's good interaction.

- Elevation of image: Russia's participation in the Kyoto Protocol and its ratification will improve Russia's image as the largest carbon emitter country in the world. With veto rights obtained by Russia after the United States refused to participate, Russia would be considered as the 'savior.' Therefore, the Russian government's move will be seen positively by the international community.

\section{Russia's Participation and Protocol's Internalization}

With the Kyoto Protocol's ratification, Russia needs to prepare a legislative and institutional framework to implement mechanisms within the Kyoto Protocol domestically. From 2006 to 2009, as many as 5 (five), legislative actions were born $^{12}$ :

a. Government Regulation (Order) of the Russian Federation concerning the establishment of a Russian carbon unit registry to fulfil commitments under the Kyoto Protocol (2006);

b. Government Regulation (Order) of the Russian Federation concerning the establishment of a system for anthropogenic emissions assessment based on its source and elimination by the removal of greenhouse gases not regulated by the Montreal Protocol on ozone-depleting substances to fulfill commitments under the Kyoto Protocol Article 5, paragraph 1 (2006);

c. Government Regulation of the Russian Federation concerning procedures for the acceptance and control of the progress of project implementation under Articles 6 and 17 of the Kyoto Protocol (2007);

d. Government Regulation (Order) of the Russian Federation concerning the simplification of procedures for the acceptance, implementation, and control of projects under Articles 6 and 17 of the Kyoto Protocol (2009).

e. Government Regulation (Order) of the Russian Federation regarding the assignment of the Savings Bank of Russia Joint Stock Company as an entity with the power to participate in the trade of greenhouse gas emissions with the aim of fulfilling the commitment of the Russian Federation on the limitation and reduction of measured greenhouse gas emissions (2009).

12 Federal Service for Hydrometeorology and Environmental Monitoring. 2014. First Biennial Report of The Russian Federation. Moscow: Russia. 
The Action Plan on the Kyoto Protocol was made and agreed with the leading agencies appointed by Russia to be responsible for handling the implementation of the Kyoto Protocol, namely the Ministry of Natural Resources (MNR) and the Russian Federal Service for Hydrometeorology and Environmental Monitoring (Roshydromet). Russia also created a national system to monitor greenhouse gas emissions and policies that have been poured into the Socio-Economic Development Program for the MediumTerm Perspective. The website containing the Russian Carbon Unit Registry was also built for the transparency of the carbon registry data collection. ${ }^{13}$ In 2009 , Russia formulated Climate Doctrine, which contained domestic climate policy to pay more attention to its carbon emissions. It is seen that Russia was already in the process of institutionalizing its commitment to implementing the Kyoto Protocol.

Furthermore, The Russian government and Russian business community had very high expectations of the Kyoto Protocol's mechanism, specifically the implementation of the JI project in Russia. The biggest energy companies in Russia, namely OAO RAO UES and Gazprom, supported the Kyoto Protocol's ratification because they saw the potential of the JI project, which was expected to improve energy efficiency and technology exchange. ${ }^{14}$

To implement the Doctrine, Russia needs to have an institutional and legislative framework so that successful project implementation efforts attract investors. Therefore, a collaboration with the business community is significant. However, Russia failed to develop an adequate framework, starting from the agency responsible for implementing the Kyoto Protocol to the uncertainty of the

\footnotetext{
13 Website could be accessed via http://www.carbonunitsregistry.ru/

${ }^{14}$ Firsova and Taplin, 2008.
}

administrative system, including unclear incentive system, which led to fraud and corruption.

There is no clear division of responsibility between Russian national bodies. The project administration process does not channel funds directly to the project investment's recipient body, but through agency authority in person. The unclear legislative mechanism makes a complicated registration process. Anna Korppoo identified problems that hampered the running of the JI project in Russia in three aspects: institutional and legislative frameworks, readiness for implementation, and project funding from local co-funding. ${ }^{15}$ as a result, more than $100 \mathrm{JI}$ projects failed to be completed in 2009, with potential emissions reductions of around 240 million tons of CO2e. More than 40 plans that have registered have also not been followed up until the end of 2009. ${ }^{16}$

Then, the most substantial reason for ratifying is the potential profit from the sale of Russian 'hot air'. Nevertheless, the income earned from emissions trading is not as high as predicted. "Potential hot air" buyers turned out to choose to buy other countries' carbon credits other than Russia. One of them is the European Union, which stated that they are more inclined to buy surplus AAUs that do not originate from 'hot air,' which is a surplus obtained through concrete greening emissions projects. In contrast, Russia's surplus is a result of its economic transition from Soviet times.

In the announcement of Russia's withdrawal in 2010, it was officially stated that the main reason was the lack of

\footnotetext{
15 Anna Korppoo, "Russian energy efficiency projects: lessons learned from Activities Implemented Jointly pilot phase". Energy Policy 33 (2008), 113-126.

16 Shishlov I. (2011). Joint Implementation in Russia: on track to overtake Brazil as the thirdlargest supplier of Kyoto offsets. http://www.cdcclimat.com/Climate-Brief-no8Joint.html
} 
participation in other primary greenhouse gas producer states. It also said that countries committed in the second commitment period had non-environmental reasons such as promoting

clean technology standards. Russia said it would join an environmental agreement which is covering all major emitters of greenhouse gases. The United States has withdrawn from the Kyoto Protocol. When Russia did the same, it shows that the Kyoto Protocol loses another world's largest polluter. Therefore, the mitigation rate could be affected. This situation also stops Russia from participating in mechanisms the Kyoto Protocol provides, such as emissions trading and JI.

\section{Table 1. Expectation and Reality of the Kyoto Protocol Implementation}

\begin{tabular}{|c|c|c|}
\hline No & Expectation & Reality \\
\hline 1. & $\begin{array}{lr}\text { Gaining } & \text { benefit } \\
\text { from } & \text { emission } \\
\text { trading } & \\
\end{array}$ & $\begin{array}{l}\text { Buying countries are } \\
\text { uninterested } \\
\text { Low carbon unit price }\end{array}$ \\
\hline 2. & $\begin{array}{l}\text { Gaining } \\
\text { investments from } \\
\text { JI project }\end{array}$ & $\begin{array}{l}\text { Domestic legislative } \\
\text { framework is inadequate; } \\
\text { thus, investors choose the } \\
\text { other countries }\end{array}$ \\
\hline 3. & $\begin{array}{l}\text { Having a bigger } \\
\text { role in Protocol } \\
\text { Kyoto negotiation. }\end{array}$ & $\begin{array}{lr}\text { Gains } & \text { bigger } \\
\text { responsibility and burden } \\
\text { in climate change } \\
\text { mitigation }\end{array}$ \\
\hline 4. & $\begin{array}{l}\text { Emission limit is } \\
\text { far enough to be } \\
\text { reached; hence } \\
\text { there's no need for } \\
\text { change in the } \\
\text { economy. }\end{array}$ & $\begin{array}{l}\text { The second commitment } \\
\text { period increased the } \\
\text { emission reduction target } \\
\text { to } 18 \% \text {. The first } \\
\text { commitment period }(\%) \\
\text { was already concerning } \\
\text { for economic growth. }\end{array}$ \\
\hline
\end{tabular}

Source: Authors

The table shows the expectations and reality of the Kyoto Protocol after being implemented. When what was allegedly potential to benefit Russia was not achieved, it was a rational action for Russia to withdraw. In the absence of significant profits, while remaining within the Kyoto Protocol, Russia has resigned and focused on what becomes its national interest.

Table 2. Cost and benefit to settle in second commitment period of Kyoto Protocol

\begin{tabular}{|c|c|}
\hline Cost & Benefit \\
\hline $\begin{array}{l}\text { Emissions need to be } \\
\text { controlled so that it } \\
\text { will have an impact on } \\
\text { economic growth; }\end{array}$ & $\begin{array}{l}\text { Emissions Need to } \\
\text { Be controlled to } \\
\text { boost the efficient } \\
\text { Energy sector. }\end{array}$ \\
\hline $\begin{array}{l}\text { 'Hot air' from the first } \\
\text { commitment period } \\
\text { cannot be sold when it } \\
\text { enters the second } \\
\text { commitment period; }\end{array}$ & $\begin{array}{lr}\text { The IET } & \text { mechanism } \\
\text { could } & \text { encourage } \\
\text { domestic } & \text { climate } \\
\text { policy; } & \end{array}$ \\
\hline $\begin{array}{l}\text { Cannot utilize the } \\
\text { mechanisms in the } \\
\text { Protocol; }\end{array}$ & $\begin{array}{l}\text { It can still use the } \\
\text { mechanisms. But } \\
\text { looking at the results } \\
\text { of the joint } \\
\text { implementation, } \\
\text { Russia needs an } \\
\text { adequate domestic } \\
\text { legal framework; }\end{array}$ \\
\hline $\begin{array}{l}\text { Russia will be bound } \\
\text { by the rules of the } \\
\text { Kyoto Protocol, } \\
\text { limiting its emissions } \\
\text { income, which } \\
\text { hampers its economy, } \\
\text { which is dominated by } \\
\text { the fossil fuel of } \\
\text { energy sector. }\end{array}$ & $\begin{array}{l}\text { Russia will be } \\
\text { considered as a } \\
\text { country concerned } \\
\text { with the issue of } \\
\text { climate change in the } \\
\text { international arena. }\end{array}$ \\
\hline
\end{tabular}

Source: Authors

The table above shows a cost and benefit calculation if Russia stays to participate in the Kyoto Protocol's second commitment period. Another additional impact on the economy is Russia would also become an industrial country that is under commitment to limit its emissions. The United States, China, Canada, and other industrialized countries did not participate, and they have withdrawn from the Kyoto Protocol. Therefore, if Russia 
settled, it reduces its competitiveness to grow its economy.

The consideration of prioritizing the country's agenda to continue to use its fossil fuel commodities is a manifestation of efforts to power maximization. Russia still needs to rebuild its economy since its downfall in the Soviet Union era. For that reason, the Russian government relies on the oil and gas sector. Russia's energy and raw materials sector covered $50 \%$ of its budget revenues, more than $70 \%$ of Russia's exports, contributed $100 \%$ to Russian stabilization funds, and around 5\% employment. ${ }^{17}$

Meanwhile, there was a fluctuation of revenue from oil and gas, due to some external and internal problems: international scale conflict - Iraq -Kuwait War 1990s and Iraq- US conflicts in the year of 2000s, which affected world oil prices. (2) Other countries' domestic political crisis such as Venezuela's unrest in 2002 - 2003; (3) 1998's Financial Crisis which affected three Asian countries: South Korea, Thailand and Indonesia and influence their purchasing power for oil and gas. (4). Russia's territorial dispute with Georgia in 2008.

The Iraq-Kuwait war in 1990 caused another oil shock across the globe. The Soviet Union's GDP during that shock equaled about 776.8 billion dollars, and the country was the world's seventh economy. However, the economic programs of the Soviet Union's leaders failed at that point, and the Soviet Union's society faced many difficulties. Asian tigers and the Russian Federation's financial crisis caused the next oil price shock in 1998. On the one hand, Thailand, South Korea, and several other East Asia countries decided on changing the nature of their currency, imposing a severe shock on the financial markets.

\footnotetext{
${ }^{17}$ Balov VN "The role and the place of the mineral sector in socio-economic development of Russia" (in Russian). Bulletin 'Ispolzovanie i ochrana prirodnich resursov v Rossii’ 6:52-54.
}

On the other hand, Russia devalued its currency as an OPEC nonmember. As a result, the petroleum price in 1998 sank to 12 dollars per barrel. In other words, petroleum prices fell to its lowest level since 1972. The Russian Federation's GDP growth per year turned $-5.8 \%$, and the value of this country's petroleum exports dropped to 14.5 billion US dollars. Another oil price shock took place in 2003, due to Venezuela's unrest and the Second Persian Gulf War (the US- Iraq war). The Iraq crisis, which was one of the OPEC's petrostates, created disorder in the supply of petroleum across the globe. The internal turmoil in Venezuela during 2002 and 2003 imbalanced petroleum and gasoline production in this country. As a result, petroleum prices took a sudden rise from about 25 dollars in 2002 to 38.3 dollars by the end of 2003. The oil price increase during this period brought about a remarkable increase in government revenues for Russia. The vast budget was used for the reconstruction and modernization of this country's economy (Bochkarev, 2006). According to the statistics by the Energy Information Administration, Russia increased its petroleum production during that shock from 7,6 -9,2 million barrels per day from 2002 to $2004 .^{18}$ The volume of petroleum exports of the Russian Federation also rose from 291 billion dollars in 2002 to 590 billion dollars in 2004, respectively.

Meanwhile, another oil price fluctuation happened during the years 2007 to 2009 , following the downturn in world oil production and the conflict in oil demand, due to Russia's domestic issues and some other global unrest. In this period, the world oil prices rose from 50 dollars per barrel at the beginning of 2007 ,

\footnotetext{
18 Ludmila Popova, Farkhondeh Jabalameli, and Ehsan Rasoulinezhad, Oil Price Shocks and Russia's Economic Growth: The Impacts and Policies for Overcoming Them, Journal of World Sociopolitical Studies, Vol. 1, No. 1, 2017, pp. 1-31
} 
Nur Yasmin Ghafiel, Paramitaningrum | Analysis Of Russia's Approach To Kyoto

Protocol: Russia's Withdrawal From Second Commitment Period (2013-2020)

to 140 dollars per barrel in summer 2008. in 2009. At the same time, Russia had a significant recession because of its military dispute with Georgia and the decrease in the substantial Urals crude oil prices. According to the statistics from Russia's central bank, the volume of crude oil exports reached from 121 billion dollars per day in 2007 to 161 billion dollars in 2008 and 100 billion dollars in 2009. Several global unrests in the first half of 2011 influenced world oil prices due to various reasons, such as earthquakes, tsunamis, the nuclear power plant explosion in Japan, the Arab Spring, Libya's civil war, and as the terror of Bin Laden. Here, the world oil prices reached from approximately 80 dollars per barrel to 120 dollars. Those issues contributed to Russia's increasing income. The customs' data of the Russian Federation shows that the revenue from petroleum exports of the country increased from 135 billion dollars in 2010 to about 181.8 billion dollars in 2011. Moreover, the oil export revenue shares equaled $53.1 \%$ of
After that, it decreased to about 70 dollars Russia's total exports in 2011. In sum, Russia has been focusing on its oil capacity to stabilize its economy, since it influences Russia's power performance.

Furthermore, Russia's oil capacity correlates with Russia's position by remaining within the Kyoto Protocol. Therefore, Russia needs to develop better mechanisms to limit its greenhouse gas emissions to meet the Kyoto Protocol targets. By the time of this research, Russia is still classified as critically insufficient ${ }^{20}$ in handling climate change. Below is the data on emissions produced by Russia in the period before and entering the second commitment period of the Kyoto Protocol; they are as follows:

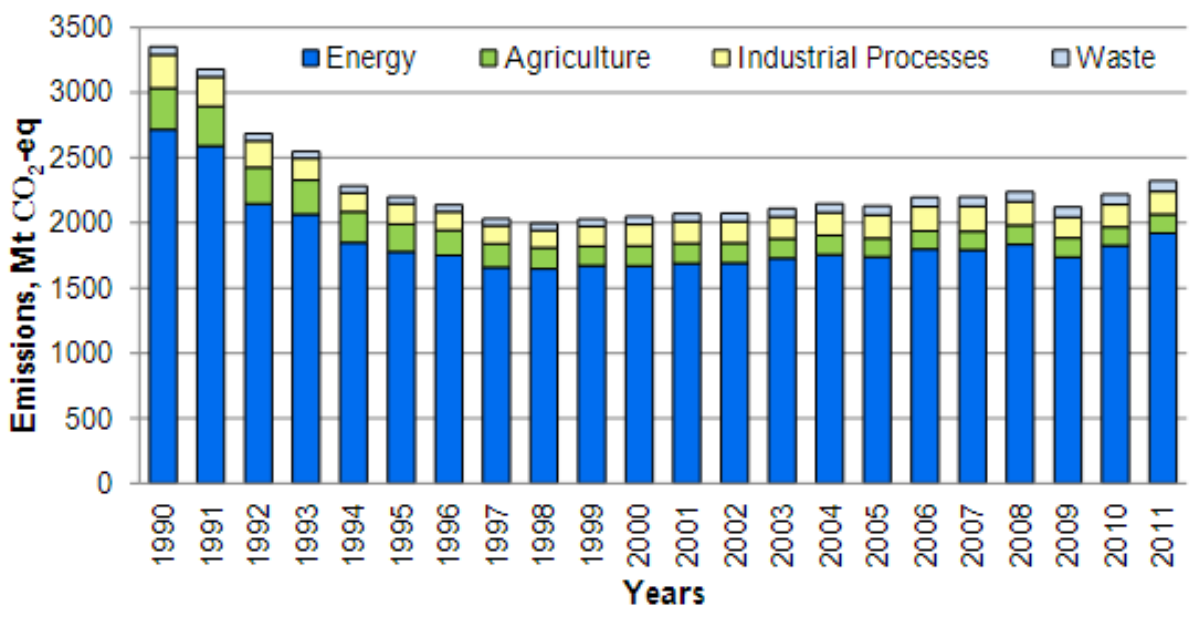

Figure 1. Russian emission data 1990-2011

Source: Federal Service of Hydrometeorology and Environmental Monitoring of the Russian Federation, $2014^{19}$

20. The Climate Action Tracker defines the term "critically insufficient" is one of the lowest groups in the commitment to be far outside the range of fair and inconsistent doses to maintain heating levels below 2 degrees Celsius from the limit of 1.5 degrees Celsius from the Paris Agreement. If all government targets are at this level, hating will exceed 4 degrees Celsius

19 Russian Federation, Federal Service for Hydrometeorology and Environmental Monitoring of the Russian Federation, First Biennial Report of the Russian Federation (for UNFCCC) (Moscow, 2014). 
The Kyoto Protocol bound the figure above shows that Russia's emissions did not experience significant changes in the period before, during, and after Russia. That figure also describes that it would not be any significant differences even when this country withdrew from the Protocol. In the first commitment period, Russia was not needed to reduce emissions and instead had a surplus of 'hot air' due to its economic transition. Nevertheless, in the second commitment period, the surplus was no longer used, and the emission reduction target was further increased, from $5 \%$ to $18 \%$ from 1990 levels. Thus, Russia would need to limit its energy use and fossil energy extraction, while these commodities were the main supporters of the economy Russia

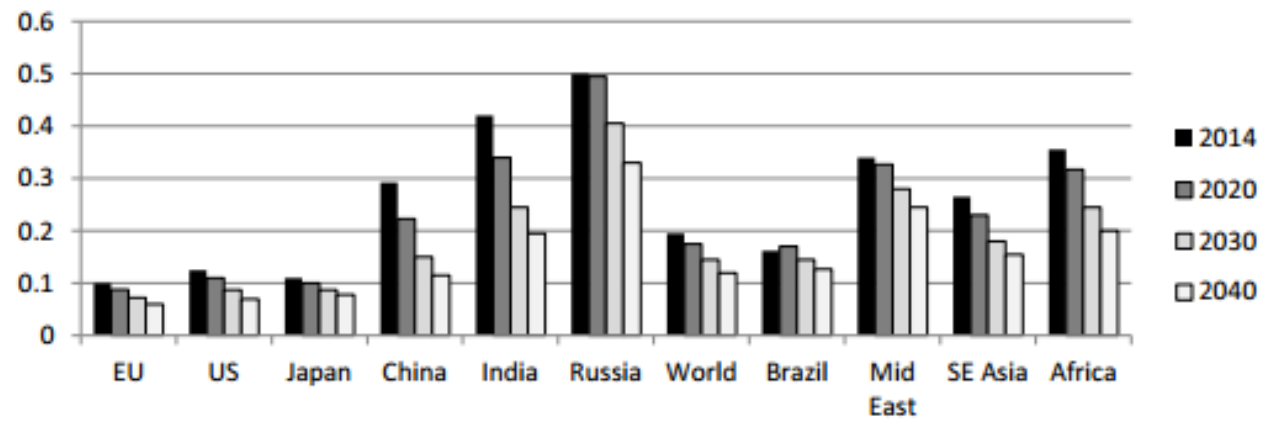

Figure 2. Projection of fossil fuel energy consumption in industrial countries 2014-2040 Source: International Energy Agency, 2016 $6^{21}$

Russia has the highest energy use projection, poured through its "Russian Energy Strategy until 2035" indicating that Russia will continue to use existing resources for its economic growth. ${ }^{22}$ Therefore, Russia's involvement in the Kyoto Protocol will affect its industrial capacity. Later on, it also hampers Russia's economic growth, mainly because Russia is bound to commit to meet its emission reduction targets. Russian emissions have continued to grow since 1998 by as much as $15 \%$ until 2006. In the same year, a $6.7 \%$ GDP growth helped increase greenhouse gas emissions by $2.6 \%$. In 2000, President Vladimir Putin had set a target to double GDP by 2010, a target that would hamper

${ }^{21}$ International Energy Agency (IEA), World Energy Outlook 2016 , http://www.iea.org/newsroom/news/2016/november/ world-energy-outlook-2016.html

${ }^{22}$ Alexey Kokorin, Korppoo, A., "Russia’s Ostrich Approach to Climate Change and the Paris Agreement", CEPS Policy Insights No. 2017-40 (Brussels: CEPS, 2017)
Russia to reduce its emissions. ${ }^{23}$ Consequently, commitments with regimes such as the Kyoto Protocol will be a barrier for Russia.

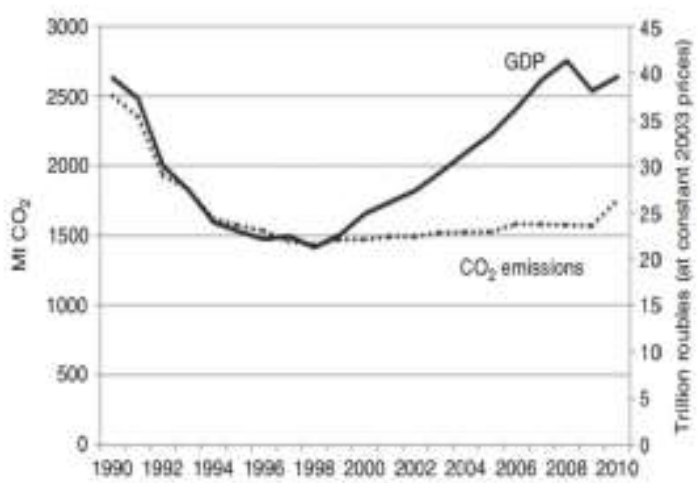

Figure 3. Increased GDP and $\mathrm{CO} 2$ emissions in Russia 1990-2010 Source: Sharmina et al, $2013^{24}$

\footnotetext{
${ }^{23}$ Anna Korppoo, Moe, A. "Russian Climate Politics: Light at the End of the Tunnel?", Climate Strategies Briefing Paper, (Oxford Climate Policy, 2007) http://climatestrategies.org/wpcontent/uploads/2007/04/russia-politics-bp.pdf

24 Maria Sharmina, Anderson, K., Larkin, A., "Climate Change Regional Review: Russia", (WIREs
} 
The graph above shows an increase in GDP accompanied by $\mathrm{CO} 2$ emissions in Russia. Russia's energy activity is the most significant contributor to emissions and GDP in Russia (See Figure 1). For that reason, restrictions on emissions will have an impact on Russia's GDP growth.

It can be concluded that based on the offensive realism assumption that the state will maintain its survival by increasing its power capability. The state will tend to direct its policies of power maximization and selfhelp, in response to an international system of anarchy so that the state needs to improve its competitive capabilities. For Russia, following what is stated in its national interest official documents, economic strength is the country's top priority that needs to be maintained and maximized. Thus, the utilization of energy resources is intensified to strengthen The Russian economy, since that is a major element in Russia's power maximization efforts. While energy resources are Russia's primary sources of wealth, therefore, Russia will allocate all resources to secure this sector, including on how to gain more benefits from Russia's international partnership.

By participating in the Kyoto Protocol's second commitment period, those above-mentioned interests will be threatened because Russia will need to limit its carbon emissions. This limitation will affect Russia's oil production process and the consumption or utilization of oil resources for development and export activities. Oil, like nature, gas is an essential revenue for Russia. Therefore, Russia's national interests in the energy sector would be above the global agenda of climate change and the self-help principle.

Furthermore, Russia already got its membership in the WTO, with the EU full supports. Being part of global and international trade arrangements such as

Clim Change 4, 2013) pp. 373-396, doi: $10.1002 /$ wcc. 236
WTO is contributed to the creation of a right image of the Russian economy and Russia's international posture. Russia gained global recognition as a new and rising economy actor and beneficial to support Russia's economy. Such recognition also helped Russia power maximization efforts because indirectly will support Russia's economic development. Furthermore, Russia's participation in WTO and its system would become the priority. Russia's commitment to the Kyoto Protocol is considered less important because it will not have similar recognition that Russia gained from WTO.

\section{Conclusion}

Russia, under President Vladimir Putin's administration, sought to restore Russia to become a world power. Participating in the Kyoto Protocol was expected to be one of the steps to realize this ambition. However, Russia's ratification into the Kyoto Protocol was not because of the environmental reasons, which are to protect the planet and mitigate climate change, but rather to gain profits. Russia hoped-for benefits from its ratification, starting from the ease of joining the WTO to increasing revenues from trading in carbon emissions.

Russia's withdrawal from the second commitment period was following the assumption of offensive realism. Russia has an ambition for power maximization through its economic growth; hence the Russian government protects its main economic supporting commodities-fossil fuel energy. The state as a rational actor will prioritize the decision that is more profitable for their country, and involvement in environmental negotiations will only be used as a tool to achieve his interests. The Kyoto Protocol, as stated by Berditsky, was no longer in the interests of Russia, so Russia decided to withdraw. Additionally, numerous factors that also contribute to this are:

- Changes in regulation and mechanisms in the Kyoto Protocol's second-period commitment did not 
put Russia in an advantageous position.

- The dependency of the Russian economy to fossil fuel energy export.

- Lack of contingency and certainty within the government that there were different opinions regarding the Kyoto Protocol ratification.

- No public pressure to the Russian government to enforce the Protocol and climate policy in general.

- Russia's perception of climate change that it would not affect their country negatively and would rather be beneficial for their economy.

For Russia, national interest is to increase its power capacity in the form of military capabilities and economic improvement. Besides that, other supporting factors are Russian expectations that are not in line with reality. Domestically, the Russian government has not prepared an adequate framework for implementing the Kyoto Protocol mechanism. Thus, investors tend to choose to invest in other countries. Emissions trading also produces no results as expected, mainly because of the buyer's country preferences and the decline in the price of carbon credits on the international carbon market. Then, the absence of internal pressure or government interest in climate change makes this issue less prioritized and considered in Russia. With the risks to the Russian economy, especially in the energy sector, Russia's decision to back down is no other to safeguard its national interests.

Russia's withdrawal from the Kyoto Protocol's second commitment period was mainly due to Russia's prioritization of national interest over global interest. Presumably, climate change is a threat to the whole world, but it has not been a major concern for Russia. When scientific findings show that climate change is advantageous for Russia, this country applied a self-help approach to this issue. Thus, the authors conclude that the issue of climate change, including the Kyoto Protocol, has not been a top priority in policy orientation and part of Russia's national interests. Until then, Russia will continue to maximize its economic growth even though it means that Russia must continue to use fossil energy.

Russia's dependence on its energy is detrimental to this country in the long run. Thus, actions need to be anticipated, such as the provision of energy diversification, energy efficiency, and specifically the development of renewable energy. Therefore, slowly, Russia can help the international community by reducing greenhouse gases in the design of a mechanism that is in line with its domestic situation and does not hurt the economy.

Russia's decline and these factors did not make Russia abstain entirely from the issue of climate change. Russia still has a crucial role to play in the future of international climate governance. Because Russia is a country with abundant fossil energy reserves, the most significant fossil energy exporter, and a country with extensive blue carbon reserves. By developing adequate forestry and energy policies, Russia could have a major influence on global climate change mitigation efforts. 
Nur Yasmin Ghafiel, Paramitaningrum | Analysis Of Russia's Approach To Kyoto

Protocol: Russia's Withdrawal From Second Commitment Period (2013-2020)

\section{DAFTAR PUSTAKA}

Balov VN (2006) "The role and the place of the mineral sector in socio-economic development of Russia" (in Russian). Bulletin 'Ispolzovanie i ochrana prirodnich resursov v Rossii' 6:52-54 in Firsova, A., Taplin, R. (2008) "A Review of Kyoto Protocol Adoption in Russia: Joint Implementation in Focus", Transit Stud Rev (2008) 15:480-498, DOI 10.1007/s11300-008-0027-0, Springer

Barysch, Katinka, Robert Cottrell, Franco Frattini, Paul Hare, Pascal Lamy, Maxim Medvedkov, and Yevgeny Yasin (2012), "Russia and the WTO" Centre for European Reform, https://www.cer.eu/sites/default/files/publications/attachments/pdf/2011/p394_russia_ wto-1663.pdf

Buchner B, Dall 'Olio S (2005) Russia and the Kyoto Protocol: the long road to ratification. Transit Stud Rev, 12,2: 349-382

Climate Action Tracker, Country Assessment: Russian Federation, accessed on January 2018 through http://www.climateactiontracker.org/countries/russian-federation/

Dunne, T M. Kurki, S. Smith, (2012), International Relations Theory: Discipline and Diversity, 3rd Edition, pp. 77-93, Oxford: Oxford University Press

Elman, Colin, (2007), "Realism", International Relations Theory for the Twenty-First Century, Routledge: Oxon, pp. 12-20

Firsova, A., Taplin, R. (2008) A Review of Kyoto Protocol Adoption in Russia: Joint Implementation in Focus, Transit Stud Rev, 15:480-498, DOI 10.1007/s11300-0080027-0, Springer

Goldenberg, S., (2010), "Cancun Climate Change Conference: Russia Will Not Renew Kyoto Protocol", The Guardian, December 10 2010, accessed through www.theguardian.com/environment/2010/dec/10/cancun-climate-change-conferencekyoto.

Golub, A., Cozijnsen, J., Petsonk A., (2009), "Linking Russia with the European and global greenhouse gas emissions trading markets: three paths for greening the Russian assigned amount under the Kyoto Protocol", Mitig Adapt Strateg Glob Change, 14:433-453, DOI 10.1007/s11027-009-9179-4, Springer

Grubb, Michael (2016), "Full legal compliance with the Kyoto Protocol's first commitment period - some lessons", Climate Policy, 16: 673-681, https://doi.org/10.1080/14693062.2016.1194005

Henry, L., Sundstrom, L., (2012): "Russia's Climate Policy: International Bargaining and Domestic Modernisation", Europe-Asia Studies, 64:7,1297-1322 doi.org/10.1080/09668136.2012.701388

International Energy Agency (IEA) (2016) World Energy Outlook 2016, Accessed on July 2018 through http://www.iea.org/newsroom/news/2016/november/world-energyoutlook-2016.html

Kokorin, A., Korppoo, A., (2017) "Russia's Ostrich Approach to Climate Change and the Paris Agreement", CEPS Policy Insights No. 2017-40

Korppoo, A., Moe, A. (2007). "Russian Climate Politics: Light at the End of the Tunnel?", Climate Strategies Briefing Paper, April 2007. Accessed on June 2018 through http://www.climatestrategies.org/reportfiles/russia_politics_bp.pdf

Korppoo, A., Vatansever, A (2012), “A Climate Vision for Russia: From Rhetoric to Action”. Carnegie Policy Outlook Ed. August 2012 
Nur Yasmin Ghafiel, Paramitaningrum | Analysis Of Russia's Approach To Kyoto

Protocol: Russia's Withdrawal From Second Commitment Period (2013-2020)

Korppoo, Anna (2004), Russia and Compliance under Kyoto: An Institutional Approach. Chatham House Sustainable Development Programme Briefing Note SDP BN 4/01, Accessed on June 2018 through https://www.riia.org/index.php?id?175

Korppoo, Anna (2005) "Russian energy efficiency projects: lessons learnt from Activities Implemented Jointly pilot phase". Energy Policy 33 (1):113-126

Lioubimtseva, Elena (2010), Russia's Role in the Post-2012 Climate Change Policy: Key Contradictions and Uncertainties, Grand Valley State University, Forum on Public Policy

Mearsheimer, John J. (2001), The Tragedy of Great Power Politics, New York: Norton

Morel, R. (2013). How the negotiators tackled the "hot air" issue for the second commitment period of the Kyoto Protocol. http://www.cdcclimat.com/How-the-negotiators-tackledthe.html

Popova, Ludmila, Jabalameli, Farkhondeh, and Rasoulinezhad, Ehsan., (2017): Oil Price Shocks And Russia's Economic Growth: The Impacts and Policies for Overcoming Them, Journal of World Sociopolitical Studies, 1: 1: pp. 1-31

Russian Federation, Energy Strategy of the Russian Federation until 2035. Ministry of Energy of the Russian Federation. (http://minenergo.gov.ru/node/1920).

Russian Federation (2000), National Security Concept of the Russian Federation, January 10 2000, accessed on July 2018 through http://www.mid.ru/en/foreign_policy/official_documents//asset_publisher/CptICkB6BZ29/content/id/589768

Russian Federation (2007) National Report of the Russian Federation on the determination of the assigned amount, Moscow

Russian Federation (2014), Federal Service for Hydrometeorology and Environmental Monitoring of the Russian Federation, First Biennial Report of the Russian Federation (for UNFCCC), Moscow: Russia

Sharmina, M., Anderson, K., Larkin, A., (2013), "Climate Change Regional Review”, WIREs Clim Change 4:373-396, DOI: 10.1002/wcc.236

Shishlov, I. (2011). Joint Implementation in Russia: on track to overtake Brazil as the thirdlargest supplier of Kyoto offsets. http://www.cdcclimat.com/Climate-Brief-no8Joint.html

UNFCCC (1998) Kyoto Protocol. Accessed in May 2018 through https://unfccc.int/sites/default/files/kpeng.pdf

UNFCCC (2018) Kyoto Protocol Introduction https://unfccc.int/process/the-kyoto-protocol

Walsh, Nick Patton. (2004), "Russian vote saves Kyoto Protocol". The Guardian, October 23 2004. Accessed this through https//www.guardian.com/world/2004/23/oct/society.russia

Yulkin, M.A. (2007). "Kyoto protocol and the possibilities for reducing greenhouse-gas emissions in the Russian metallurgical sector". Metallurgist 51 (3-4):191-194 